\title{
RESOLUSI KONFLIK LAHAN ANTARA PELADANG PENDATANG DAN PELADANG SETEMPAT DI KECAMATAN BATANG MERANGIN KABUPATEN KERINCI
}

\author{
Neza Helpitia \\ Jurusan Administrasi Publik Fakultas Ilmu Sosial Universitas Negeri Padang \\ Email: neza_helpitia@yahoo.com
}

\begin{abstract}
This study aimed to determine the factors causing land conflicts and how conflict management efforts applied in the resolution of land conflicts between immigrant farmers and local cultivators in Batang Merangin District, Kerinci Regency. This study was a qualitative research with descriptive method. Data in this study were collected through interview and documentation study. Informants in this study were determined by purposive sampling technique and snowball sampling. Data were analyzed with interactive analysis model. The results of this study indicated that factors causing land conflicts include: a) seizing land resources between immigrant farmers and local cultivators; b) poor communication between immigrant farmers and local cultivators; c) the social jealousy of local cultivators on the success of immigrant farmers in cultivating the land; d) theft, looting, incarceration, and burning of farm houses belonging to immigrant farmers by local cultivators. Conflict management in this case were carried out in two ways, namely negotiation and mediation by local government of Kerinci Regency.
\end{abstract}

Keywords: Conflict resolution, immigrant farmers, local cultivators.

\section{Pendahuluan}

Bercocok tanam adalah pekerjaan yang paling banyak dilakukan di Indonesia sebagai negara yang berkembang, terutama masyarakat di pedesaan, dengan memanfaatkan lahan yang dimilliki dengan menanam tanaman yang dianggap bisa sebagai mata pencaharian. Kondisi ini juga terjadi di Kabupaten Kerinci Kecamatan Batang Merangin yang sebagian besar penduduknya bercocok tanam di ladang dan mengolah lahan perkebunan/pertanian, seperti menanam kulit manis (cassiavera), kopi, dan tanaman holtikultura lainnya.

Namun seiring dengan meningkatnya pertumbuhan penduduk yang tidak berbanding lurus dengan jumlah sumber daya alam yang tersedia, dalam arti lahan untuk bercocok tanam menjadi langka, kegiatan masyarakat pun terbatas untuk mencari tempat bercocok tanam dan adanya sebagian dari mereka mencari lahan untuk berladang dengan cara meminjam lahan perladangan. Namun kondisi ini akhirnya menjadi pemicu terjadinya konflik dalam masyarakat, seperti konflik yang terjadi di Kabupaten Kerinci antara peladang pendatang dan peladang setempat di Kecamatan Batang Merangin yaitu perebutan sumber daya berupa lahan perladangan. 
Berdasarkan SK No.150/VIII-1979 Pemerintah Daerah Kabupaten Kerinci asal mula peladang pendatang masuk berladang di daerah Kecamatan Batang Merangin itu atas anjuran Pemerintah Daerah Kabupaten Kerinci dalam mensukseskan Pelita III (1 April 1974-31Maret 1979) untuk meningkatkan hasil pertanian untuk kepentingan masyarakat supaya tercapainya masyarakat adil dan makmur. Sehubungan dengan itu maka dilaksanakanlah pembukaan areal perladangan baru/persawahan baru di daerah Kecamatan Batang Merangin dengan memberangkatkan peladang pendatang secara berombongan. Peladang pendatang ini masih merupakan penduduk asli Kabupaten Kerinci tetapi berasal dari Kecamatan yang berbeda.

Setelah berpuluh-puluh tahun peladang pendatang menggarap lahan perladangan, sekarang keluar surat edaran dari Depati Muara Langkap yang mengatasnamakan peladang setempat berupa surat pemberitahuan No.001/LADMLT/2017 tanggal 2 Januari 2017 dan tanggal 10 Januari 2017 yang isinya menyatakan bahwa bagi peladang pendatang yang tidak mempunyai dokumen yang sah atau surat resmi dari Kepala Desa setempat maka penggarap lahan tersebut harus meninggalkan lahan perladangannya dalam waktu 3 bulan. Disamping itu, peladang pendatang hampir secara keseluruhan juga dirugikan dengan adanya tindakan pencurian, penjarahan, penyerobotan dan pembakaran rumah ladang yang dilakukan oleh oknum peladang setempat.

Resah dengan tindakan ini perwakilan dari pihak peladang pendatang pun berupaya menyelesaikan konflik ini dengan menemui pihak peladang setempat untuk duduk berunding. Peladang setempat mengatakan bahwa peladang pendatang yang berada di daerah Kecamatan Batang Merangin tidak memberikan sumbangan untuk pembangunan negeri setempat. Meski pun begitu, masyarakat peladang setempat tetap bersikeras akan mengambil lahan perladangan peladang pendatang yang diklaimnya merupakan lahan milik masyarakat peladang setempat tanpa ada ganti rugi dalam bentuk apa pun. Karena tidak ada solusi yang didapatkan oleh peladang pendatang dari peladang setempat. Pihak peladang pendatang pun tetap berupaya menyelesaikannya dengan meminta bantuan dari Pemerintah Kecamatan Batang Merangin, akan tetapi tidak juga membuahkan hasil.

Alhasil, seluruh masyarakat peladang pendatang yang berladang di daerah Kecamatan Batang Merangin yang berasal dari Kecamatan Air Hangat, Air Hangat Barat, Air Hangat Timur, Depati VII, Hamparan Rawang, Kumun Debai Pesisir Bukit dan Tanah Kampung ini pun bersatu dan sepakat membuat persatuan yang bernama Forum Masyarakat Perladangan. Mereka memutuskan upaya penyelesaian ini diserahkan kepada Pemerintah Daerah Kabupaten Kerinci untuk segera mungkin menyelesaikannya.

Pemerintah Daerah Kabupaten Kerinci merasa telah melakukan upaya penyelesaian konflik lahan antara peladang pendatang dan peladang setempat dengan mengadakan pertemuan dengan kedua belah pihak yang terlibat konflik. Sementara masyarakat peladang menilai Pemerintah Daerah sangat lambat dalam menyelesaikan konflik tersebut. Karena lamanya waktu yang terjeda dalam penyelesaian serta tidak nampaknya titik terang dari Pemerintah Daerah, akhirnya pihak peladang pendatang yang berladang di daerah Kecamatan Batang Merangin 
berkumpul dan kompak untuk melakukan demo aksi damai pada tanggal 7 Februari 2017 di Kantor DPRD Kota Sungai Penuh menyampaikan aspirasi agar anggota dewan sebagai wakil rakyat membantu mencarikan solusi terhadap polemik yang mereka alami.

Pasca demo pihak peladang tadinya berpikir, besar harapan akan ada penyelesaian yang cepat dari Pemerintah Daerah apalagi didesak oleh \pm 1500 (seribu lima ratus) orang massa pendemo. Akan tetapi lagi-lagi pihak peladang pendatang merasa sangat kecewa belum ada solusi yang jelas ditambah banyaknya masalah yang dipendam diantara kedua belah pihak yang berkonflik yang tidak kunjung terselesaikan. Alhasil kedua belah pihak mengambil jalan sendiri-sendiri yang berujung bentrokan. Bentrokan ini terjadi pada tanggal 20 Maret 2017, yang menimbulkan kerugian \pm 72 unit sepeda motor milik peladang pendatang yang dibakar habis oleh massa peladang setempat dan 4 (empat) orang korban luka.

Meskipun suasana sudah kondusif, potensi konflik besar kemungkinan akan terjadi lagi. Mengingat belum adanya penyelesaian yang baik untuk kedua belah pihak. Apalagi kedua belah pihak sama-sama keras untuk mempertahankan tujuan mereka. Berdasarkan latar belakang di atas, maka peneliti telah melakukan penelitian yang difokuskan pada 1) faktor-faktor penyebab terjadinya konflik lahan antara peladang pendatang dan peladang setempat di Kecamatan Batang Merangin Kabupaten Kerinci dan 2) upaya manajemen konflik yang diterapkan dalam penyelesaian konflik lahan antara peladang pendatang dan peladang setempat di Kecamatan Batang Merangin Kabupaten Kerinci.

\section{Tinjauan Kepustakaan}

Saile (2008) menyatakan konflik adalah pertentangan atau perselisihan antara dua atau lebih kelompok etnis atau daerah. Pertentangan atau perselisihan tersebut berakibat terjadinya kekerasan yang menyebabkan korban jiwa dan kerugian materi atau harta benda serta sarana prasarana pemerintah. Lauer (2001) dilihat dari sifatnya, konflik dibagi konflik dapat dibagi menjadi konflik destruktif dan konflik konstruktif. a) Konflik destruktif merupakan konflik yang muncul karena salah satu pihak menyimpan rasa benci, perasaan tidak senang dan dendam terhadap pihak lain yang berujung pada terjadinya bentrokan-bentrokan yang mengakibatkan korban jiwa dan kerugian harta benda, b) Konflik konstruktif adalah konflik yang muncul karena adanya perbedaan pendapat dalam menghadapi masalah. Konflik perbedaan pendapat tersebut akan menghasilkan perbaikan untuk ke depannya.

Sedangkan, menurut Rauf (2001) jika dilihat dari pihak-pihak yang terlibat konflik, maka dapat dibedakan atas dua macam yaitu: a) konflik individual adalah konflik yang antara dua orang yang tidak melibatkan kelompok masing-masing. Faktor penyebab dari konflik ini biasanya adalah masalah pribadi, sehingga orang-orang yang terlibat dalam konflik ini hanyalah orang-orang yang bersangkutan saja. Contohnya adalah perkelahian antara dua orang yang disebabkan oleh ketersinggungan salah satu pihak, b) konflik kelompok adalah konflik yang terjadi antara dua kelompok atau lebih. Konflik pribadi biasanya dapat dengan mudah menjadi konflik kelompok karena adanya kecenderungan 
yang besar dari individu yang berkonflik untuk melibatkan kelompokkelompoknya masing-masing. Di samping itu solidaritas kelompok yang tinggi sehingga ada kecenderungan anggota kelompok untuk membantu seorang anggota kelompok yang terlibat dalam konflik.

Selanjutnya Usman Pelly (dalam Syamsir, 2002) menyatakan setidaknya ada tiga sumber ketidakserasian sosial yang ada pada saatnya merupakan faktor penyebab timbulnya kesenjangan sosial atau konflik sosial yaitu a) perebutan sumber daya, alat-alat produksi dan kesempatan ekonomi, b) perluasan batasbatas kelompok sosial budaya. Perbedaan tradisi, bahasa, hukum dan identitas sosial dapat menyatu dalam kepentingan politik yang dapat memicu konflik, kecemburuan dan berbagai prasangka sosial dalam masyarakat. Perluasan batasbatas kelompok ini dapat pula muncul dalam bentuk fisik, seperti perluasan pemukiman ke daerah kelompok etnis lain, c) gejala stereotype etnik, prasangka (prejudice) etnosentrisme, dan perilaku diskriminatif lainnya, baik yang menyangkut agama maupun adat budaya dan perilaku, bisa menjadi penghambat dalam interaksi serta pergaulan antar suku bangsa.

Sedangkan menurut Wirawan (2010) konflik dapat terjadi secara alami karena adanya kondisi objektif yang dapat menimbulkan terjadinya konflik. Kondisi yang dapat menimbulkan konflik antara lain : a) keterbatasan sumber: manusia selalu mengalami keterbatasan sumber-sumber yang diperlukan untuk mendukung kehidupannya sehingga menimbulkan perebutan ataupun persaingan untuk mendapatkan sumber penghidupan yang diperlukan, b) tujuan yang berbeda: konflik terjadi karena pihak-pihak yang terlibat konflik mempunyai tujuan yang berbeda, c) saling tergantung atau interdependensi tugas: konflik terjadi karena pihak-pihak yang terlibat konflik memiliki tugas yang tergantung satu sama lain. d) diferensiasi organisasi: salah satu penyebab konflik dalam organisasi adalah pembagian tugas tidak berdasarkan profesionalitas dan spesialisasi tenaga kerja pelaksananya, e) ambiguitas yurisdiksi: pembagian tugas yang tidak definitif akan menimbulkan ketidakjelasan cakupan tugas dan wewenang unit kerja dalam organisasi, f) sistem imbalan yang tidak layak: konflik antara karyawan dan manajemen perusahaan sering terjadi, dimana manajemen perusahaan menggunakan sistem imbalan yang dianggap tidak adil atau tidak layak oleh karyawan, g) komunikasi yang tidak baik: komunikasi yang tidak baik seringkali menimbulkan konflik atau permasalahan baru, h) beragam karakteristik sistem sosial: konflik dalam masyarakat sering muncul akibat anggota dalam masyarakat tersebut memiliki beragam karakteristik, i) pribadi orang: adanya seseorang yang memiliki sifat kepribadian yang menimbulkan konflik, j) kebutuhan: orang memiliki kebutuhan yang berbeda satu sama lain atau memiliki kebutuhan yang sama mengenai sesuatu yang terbatas jumlahnya, k) perasaan dan emosi: sebagian orang mengikuti perasaan dan emosinya saat berhubungan dengan orang lain. Sedangkan Wahyoefiles (dalam Sukardi, 2016) secara umum penyebab konflik sebagai berikut: a) konflik nilai, b) kurangnya komunikasi, c) kepemimpinan yang kurang efektif, d) ketidakcocokan peran, e) produktivitas rendah, f) perubahan keseimbangan, g) konflik atau masalah yang belum terpecahkan. 
Sementara Nurman, dkk (2002) menyatakan penyebab terjadinya konflik adalah a) adanya keinginan untuk memenuhi kebutuhan dan kepentingan politik, b) adanya keinginan untuk menyatukan kelompok, c) adanya kebencian dan kecemburuan, d) adanya perbedaan dan hubungan yang tidak serasi antara faktorfaktor statis yang mendorong keberadaan status secara pribadi diantara individu maupun kelompok, seperti pendidikan, e) adanya perampasan hak, kewenangan dan kekuasaan, f) adanya penindasan dari satu pihak terhadap pihak lain yaitu pihak-pihak terlibat dalam konflik.

Selanjutnya Wirawan (2010) mendefinisikan manajemen konflik sebagai usaha yang dilakukan pihak ketiga ataupun pihak yang terlibat konflik menerapkan strategi konflik agar mencapai resolusi yang diinginkan. Sementara Johnson (dalam Walgito, 2010) mengemukakan 5 gaya dalam mengelola konflik, yaitu a) gaya kura-kura: orang yang terlibat konflik berperilaku seperti kura-kura, lebih cenderung bersembunyi di dalam tempurungnya daripada berhadapan langsung dengan lawannya. Artinya ia lebih baik menghindar dari pokok permasalahan daripada harus berhadapan menyelesaikannya karena ia beranggapan hal tersebut akan sia-sia, b) gaya ikan hiu: pihak yang berkonflik menyelesaikan masalah dengan cara menuntut pihak lawan untuk menerima solusi yang ditawarkannya. Penyelesaian masalah seperti ini lebih mengutamakan terpenuhi tujuan pribadinya. Sementara hubungan baik dengan pihak lain tidak menjadi penting, bahkan untuk memenangkan tujuan pribadinya, ia akan bertindak keras dengan melakukan pengancaman maupun penyerangan, c) gaya kancil : orang yang menyelesaikan masalah dengan gaya ini, lebih mengutamakan kepentingan orang lain. Demi tetap terjaganya hubungan baik dengan pihak lain, tujuan pribadinya dikesampingkan artinya ia lebih baik mengalah, d) gaya rubah: orang yang melakukan penyelesaian masalah dengan gaya ini melakukan kompromi yaitu kedua belah pihak mengambil jalan tengahnya. Keduanya harus saling mengerti dan merasakan posisi lawan sehingga bisa saling mengurangi tuntutan terhadap pihak lawan. Hasilnya tujuan pribadi masing-masing pihak terpenuhi dan hubungan baik dengan pihak lawan pun tetap terjaga, e) gaya burung hantu: orang yang menggunakan gaya ini meyakini bahwa masalah merupakan hal yang harus dipecahkan dengan tetap mengutamakan tujuan pribadi dan hubunga baik. Selain itu, gaya ini juga meyakini bahwa konflik merupakan hal yang positif karena setelah terpecahkan masalah, konflik akan bermanfaat pada meningkatnya hubungan baik antar kedua belah pihak yang bertikai.

Sementara itu menurut Acep Supriadi Wahyu dan Mariatul Kiptiah (2016) mengemukakan bahwa upaya penyelesaian konflik dapat dilakukan dengan musyawarah (negotiation), konsiliasi, mediasi, dan arbitrase. Negosiasi (musyawarah) merupakan fact of life dan setiap orang melakukan negosiasi untuk mendapatkan apa yang diinginkan oleh orang lain. Negosiasi berasal dari kata bahasa Inggris, "negotiation" yang berarti berunding, bermusyawarah atau bermufakat. Penyelesaian secara musyawarah mufakat juga dapat dikenal dengan sebutan penyelesaian secara bipartit, yakni penyelesaian yang dilakukan oleh para pihak yang sedang berselisih dan orang yang mengadakan perundingan disebut negotiator. Sedangkan konsiliasi merupakan bentuk pengendalian konflik sosial utama. Penyelesaian konflik diselesaikan oleh suatu lembaga yang berwenang 
menangani masalah pertanahan. Yang berhak menyelesaikan masalah hanya lembaga konsiliasi. Selanjutnya, mediasi merupakan pengendalian konflik yang dilakukan dengan cara membuat suatu kesepakatan yang disetujui bersama-sama diantara dua pihak yang berkonflik untuk mencari pihak ketiga yang berkedudukan netral sebagai mediator dalam penyelesaian konflik. Pihak mediator berkewajiban menyelesaikan masalah konflik paling lama 30 hari kerja sejak menerima pendaftaran konflik dari pihak yang berkonflik. Sedangkan arbitrase merupakan pengendalian konflik yang dilakukan dengan cara kedua belah pihak yang bertentangan sepakat untuk menerima atau terpaksa menerima keputusan yang diberikan pihak ketiga dalam menyelesaikan konflik tersebut. Kedua belah pihak sepakat untuk menerima keputusan penyelesaiannya secara legal.

Selanjutnya Suryanef dan Syamsir (2007) mengungkapkan bahwa konflik sosial budaya sebenarnya bisa dinetralisir dengan menciptakan konsensuskonsensus. Hal ini dapat dilakukan apabila diciptakan toleransi-toleransi melalui proses komunikasi antara penduduk asli dan penduduk pendatang. Konsensus ini pada gilirannya akan dapat mengatasi perbedaan pendapat dan kepentingan di antara anggota masyarakat dan kelompok. Sehingga setiap ketegangan dan penyimpangan yang terjadi akan selalu dapat dicarikan rujukannya di dalam konsensus yang telah disepakati bersama. Dengan demikian konflik yang terjadi tidak akan menjurus ke arah kekerasan dan integrasi sosial budaya akan dapat tercapai. Upaya yang sebaiknya ditempuh adalah melalui mekanisme dialog antara kedua belah pihak secara terbuka, baik melalui forum-forum resmi seperti seminar dan diskusi, maupun melalui pertemuan-pertemuan informal pada tingkat pemimpin masyarakat dan masyarakat itu sendiri. Di samping itu perlu pula lebih digiatkan dialog-dialog melalui atau antar organisasi kemasyarakatan lintas agama dan etnik. Dengan dialog yang jujur dan terbuka diharapkan akan tumbuh saling pengertian dan akan memupus prasangka dan kecurigaan yang terjadi.

\section{Metode Penelitian}

Penelitian ini merupakan penelitian kualitatif dengan metode deskriptif dalam rangka untuk mengetahui gambaran penyelesaian konflik lahan antara peladang pendatang dan peladang setempat di Kecamatan Batang Merangin Kabupaten Kerinci. Penelitian ini dilaksanakan selama lebih kurang 6 (enam) bulan. Dalam penelitian ini peneliti menggunakan beberapa teknik pengumpulan data, diantaranya wawancara dan studi dokumentasi.

Informan dalam penelitian ini ditentukan dengan teknik purposive sampling dan snowball sampling. Informan penelitian antara lain terdiri dari pemuka masyarakat, pemuka adat, pihak pemerintah, serta beberapa masyarakat yang terlibat atau pernah terlibat dalam konflik. Uji keabsahan data menggunakan triangulasi sumber dan metode. Analisis data dilakukan dengan menggunakan teknik analisis model Miles dan Huberman (dalam Sugiyono, 2014) dengan langkah-langkah: a) reduksi data, b) penyajian data (display data), c) penarikan kesimpulan/verifikasi. 


\section{Hasil Penelitian dan Pembahasan}

\section{Faktor-faktor penyebab konflik lahan}

Saile (2008) menyatakan konflik adalah pertentangan atau perselisihan antara dua atau lebih kelompok etnis atau daerah. Pertentangan atau perselisihan tersebut berakibat terjadinya kekerasan yang menyebabkan korban jiwa dan kerugian materi atau harta benda serta sarana prasarana pemerintah. Berdasarkan temuan peneliti di lapangan, faktor yang menjadi penyebab terjadinya konflik lahan antara peladang pendatang dan peladang setempat di Kecamatan Batang Merangin Kabupaten Kerinci adalah sebagai berikut:

\section{a. Perebutan Sumber Daya}

Dari hasil penelitian yang ditemui di lapangan peladang setempat mengklaim bahwa lahan perladangan yang digarap oleh peladang pendatang adalah milik peladang setempat selaku penduduk setempat yang ber-KTP/berdomisili di Kecamatan Batang Merangin. Sementara peladang pendatang tidak terima dan menentang keras atas klaim tersebut, sebab peladang pendatang mengaku bahwa lahan perladangan yang digarap itu diperoleh secara resmi dan tertulis atas anjuran Pemerintah Daerah Kabupaten Kerinci pada 1 April 1974-31 Maret 1979 untuk mensukseskan Pelita III pada masa Pemerintahan Presiden Suharto dalam rangka untuk meningkatkan hasil perkebunan/persawahan baru. Untuk kepentingan masyarakat tersebut maka dilaksanakanlah pembukaan areal perladangan/ persawahan baru di Kecamatan Batang Merangin. Dengan demikian, maka diberangkatkanlah secara berombongan peladang pendatang yang berasal dari beberapa Kecamatan berbeda yang masih merupakan penduduk asli Kabupaten Kerinci.

Peladang pendatang pun mengolah hutan rimba yang berada di daerah Kecamatan Batang Merangin menjadi lahan perladangan seperti menanam kulit manis, kopi, dan tanaman holtikultura lainnya sebagai mata pencaharian. Pada masa-masa selanjutnya, kedua belah pihak mengaku berhak terhadap lahan tersebut sehingga terjadi perebutan sumber daya lahan perladangan yang menjadi faktor penyebab terjadinya konflik lahan antara peladang pendatang dan peladang setempat. Kondisi ini sesuai dengan pernyataan Usman Pelly (dalam Syamsir, 2002) yang menyatakan bahwa faktor penyebab timbulnya konflik sosial salah satunya yaitu perebutan sumber daya, alat-alat produksi dan kesempatan ekonomi.

\section{b. Komunikasi yang tidak baik}

Dari hasil penelitian ini ditemukan pula bahwa peladang pendatang sebagai orang luar yang masuk berladang di daerah Kecamatan Batang Merangin berdasarkan kesepakatan awal dengan peladang setempat adalah bahwa mereka harus mematuhi ketentuan adat setempat yaitu mengisi uang adat dalam bentuk ikut berpartisipasi dalam pembangunan desa setempat. Namun, dikarenakan lahan perladangan peladang pendatang sudah ada yang diwarisi pada anak cucunya, maka ada pula lahan yang sudah diperjualbelikan ke pihak lain sehingga kepemilikan lahan kebanyakan adalah orang baru. Peladang pendatang yang baru 
tersebut tidak ada lagi mengisi uang adat setempat sehingga masyarakat peladang setempat ini merasa tersinggung, diabaikan, dan tidak dihormati.

Sementara itu masyarakat peladang setempat itu sendiri tidak mengingatkan dan memberitahukan kepada peladang pendatang tentang norma-norma adat yang berlaku di daerahnya. Itu dikarenakan dalam pergaulan sehari-hari antara peladang pendatang dan peladang setempat tidak saling bertegur sapa sehingga kesulitan untuk berkomunikasi. Akibat tidak baiknya komunikasi serta ketidakterbukaan kedua belah pihak menjadi faktor penyebab terjadinya konflik lahan antara peladang pendatang dan peladang setempat di Kecamatan Batang Merangin Kabupaten Kerinci. Temuan penelitian ini sejalan dengan dengan pendapat Wahyofiles (dalam Sukardi, 2006) yang menjelaskan bahwa ada tujuh faktor penyebab konflik salah satunya yaitu kurangnya komunikasi. Selain itu, hal ini juga senada dengan pendapat Wirawan (2010) yang menyebutkan bahwa kondisi yang dapat menimbulkan konflik salah satunya yaitu komunikasi yang tidak baik. Menurutnya, komunikasi yang tidak baik seringkali menimbulkan konflik atau permasalahan baru.

\section{c. Adanya kecemburuan sosial}

Berdasarkan temuan penelitian ini juga terindikasi bahwa kerja keras peladang pendatang menggarap lahan perladangan di daerah Kecamatan Batang Merangin menuai hasil yang baik. Setiap kali panen kopi ataupun kulit manis mereka bisa menjualnya berton-ton kopi dan kulit manis dengan harga jual yang cukup fantastik. Sementara warga setempat kebanyakannya hanya bekerja sebagai tukang ojek pengangkut hasil perladangan, bahkan dalam sehari hanya dapat upah kurang lebih Rp.400.000 dari peladang pendatang. Masyarakat setempat ini tidak terima hanya sebagai penontonnya saja dan membiarkan orang luar hidup berjaya di daerahnya. Akhirnya terjadi ketimpangan sosial dan hal inilah yang menimbulkan kecemburuan sosial yang menjadi faktor penyebab terjadinya konflik lahan antara peladang pendatang dan peladang setempat di Kecamatan Batang Merangin Kabupaten Kerinci.

Kondisi di atas sesuai pula dengan pendapat Nurman, dkk (2002) yang dengan singkat dan jelasnya menyatakan bahwa penyebab terjadinya konflik adalah adanya kebencian dan kecemburuan. Selain itu juga hal ini juga sesuai dengan pendapat Usman Pelly (dalam Syamsir, 2002) bahwa penyebab konflik antara lain adalah terjadinya perluasan tradisi, bahasa, hukum dan identitas, sosial dapat menyatu dalam kepentingan politik yang dapat memicu konflik, kecemburuan dan berbagai prasangka sosial dalam masyarakat.

\section{d. Tindakan pencurian, penjarahan, penyerobotan, dan pembakaran rumah ladang milik peladang pendatang}

Temuan penelitian ini juga mengindikasikan bahwa hampir semua peladang pendatang di daerah Kecamatan Batang Merangin diresahkan dan dirugikan dengan adanya tindakan pencurian, penjarahan dan penyerobotan ladang yang dilakukan oleh oknum peladang setempat. Peladang pendatang pernah bertemu langsung dengan pelaku yang bertindak kesewenang-wenangan yang dikenali 
merupakan peladang setempat. Bahkan massa dari peladang setempat bertindak kriminal membakar rumah ladang milik peladang pendatang dan membakar \pm 72 unit sepeda motor milik peladang pendatang. Peladang pendatang sebagai pihak yang dirugikan tidak terima atas perlakuan tersebut sehingga perselisihan tersebut berujung bentrokan yang menimbulkan 4 (empat) orang korban luka. Temuan penelitian ini juga senada dengan pendapat yang dikemukakan oleh Nurman, dkk (2002) yang menyatakan bahwa penyebab terjadinya konflik anrata lain adalah adanya perampasan hak, kewenangan dan kekuasaan atau adanya penindasan dari satu pihak terhadap pihak lain yaitu pihak-pihak yang terlibat konflik.

\section{Upaya manajemen konflik antara peladang pendatang dan peladang setempat}

Wirawan (2010) mendefinisikan manajemen konflik sebagai usaha yang dilakukan pihak ketiga ataupun pihak yang terlibat konflik menerapkan strategi konflik agar mencapai resolusi yang diinginkan. Di sisi lain Lauer (2001) mengemukakan bahwa konflik destruktif merupakan konflik yang muncul karena salah satu pihak menyimpan rasa benci, perasaan tidak senang, dan dendam terhadap pihak lain yang berujung pada terjadinya bentrokan-bentrokan yang mengakibatkan korban jiwa dan kerugian harta benda.

Dilihat dari sifat konflik terkait dengan permasalahan yang peneliti kemukakan di atas, maka konflik yang terjadi di lokasi penelitian ini termasuk pada konflik yang bersifat destruktif, karena konflik lahan yang terjadi antara peladang pendatang dan peladang setempat di Kecamatan Batang Merangin Kabupaten Kerinci ini timbul karena adanya perasaan benci, kecemburuan sosial yang berujung pada bentrokan fisik diantara kedua pihak yang mengakibatkan adanya korban dan kehilangan harta benda.

Selain itu, jika dilihat dari pihak-pihak yang terlibat konflik, maka konflik ini termasuk pada konflik kelompok. Hal ini senada dengan pendapat yang dikemukakan oleh Rauf (2001) yang menyatakan bahwa konflik kelompok adalah konflik yang terjadi antara dua kelompok atau lebih dan konflik pribadi ini biasanya dapat dengan mudah menjadi konflik kelompok karena adanya kecenderungan yang besar dari individu yang berkonflik untuk melibatkan kelompok-kelompoknya masing-masing. Disamping itu, solidaritas kelompok yang tinggi sehingga ada kecenderungan anggota kelompok untuk membantu seorang anggota kelompok yang terlibat dalam konflik tanpa ingin tahu sebabsebab yang menimbulkan konfllik.

Dilihat dari bentuk konflik yang berdasarkan keterlibatan, maka dalam penelitian ini termasuk pada konflik kelompok karena ada dua kelompok yang saling bertentangan atau percekcokan yaitu kelompok peladang pendatang dan peladang setempat yang memperebutkan lahan perladangan yang berada di Kecamatan Batang Merangin Kabupaten Kerinci.

Adapun upaya manajemen konflik yang diterapkan dalam penyelesaian konflik lahan antara peladang pendatang dan peladang setempat di Kecamatan Batang Merangin Kabupaten Kerinci dilakukan dengan dua cara yaitu 
musyawarah (negotiation) dan mediasi (mediation). Hal ini dapat dijelaskan sebagai berikut:

\section{a. Musyawarah (negotiation)}

Berdasarkan hasil penelitian di lapangan terindikasi bahwa pihak peladang pendatang telah mengupayakan penyelesaian konflik secara musyawarah, mereka telah menemui Kepala Desa, Depati/Kaum Adat setempat untuk duduk berunding menyelesaikan masalah secara kekeluargaan. Namun usaha tersebut tidak menemui titik terang dikarenakan sikap pihak peladang setempat yang sangat menutup diri dan berpandangan bahwa peladang pendatang yang berada di daerah mereka seperti musuh. Johnson (dalam Walgito, 2010) mengemukakan bahwa ada 5 gaya dalam mengelola konflik salah satunya yaitu gaya kura-kura, dimana orang yang terlibat konflik berperilaku seperti kura-kura, lebih cenderung bersembunyi di dalam tempurungnya daripada berhadapan langsung dengan lawannya. Artinya ia lebih baik menghindar dari pokok permasalahan daripada harus berhadapan menyelesaikannya karena ia beranggapan hal tersebut akan sia-sia.

Dalam kasus ini, peladang setempat lebih memilih untuk menghindar, mereka tidak menerima solusi yang ditawarkan peladang pendatang. Di samping itu, mereka juga menolak untuk memberikan solusi untuk menyelesaikan konflik sehingga sikap peladang setempat menjadikan berlarut-larutnya proses penyelesaian masalah tersebut yang menyebabkan konflik tersebut semakin membesar yang berujung pada terjadinya bentrokan. Padahal sebenarnya solusi konflik bisa saja dilakukan dengan jalan musyawarah. Acep Supriadi Wahyu dan Mariatul Kiptiah (2016) dan Suryanef dan Syamsir (2002) menyatakan bahwa upaya penyelesaian konflik salah satunya dapat dilakukan dengan cara musyawarah (negotiation) atau dialog yakni penyelesaian yang dilakukan melalui dialog dan musyawarah antara para pihak yang sedang berselisih. Namun dalam kasus ini, peladang pendatang dan peladang setempat telah telah mengupayakan musyawarah namun tidak berhasil.

\section{b. Mediasi}

Tidak berhasil dengan cara musyawarah, maka penyelesaian konflik lahan antara peladang pendatang dan peladang setempat di Kecamatan Batang Merangin Kabupaten Kerinci berdasarkan data yang peneliti temukan di lapangan adalah dengan menggunakan mediasi atau pihak ketiga yang dimediatori oleh Pemerintah Daerah Kabupaten Kerinci. Upaya mediasi dalam penyelesaian konflik ini sesuai dengan pendapat yang dikemukakan oleh Acep Supriadi Wahyu dan Mariatul Kiptiah (2016) yang menyatakan upaya penyelesaian konflik salah satunya dapat dilakukan dengan mediasi (mediation) yang merupakan pengendalian konflik yang dilakukan dengan cara membuat konsensus diantara dua pihak yang berkonflik untuk mencari pihak ketiga yang berkedudukan netral sebagai mediator dalam penyelesaian konflik.

Pemerintah Daerah Kabupaten Kerinci mempertemukan kedua belah pihak dalam sebuah forum resmi Focus Group Discussion (FGD) Penyelesaian Tanah Perladangan Di Kecamatan Batang Merangin. Dari beberapa kali pertemuan dibuat kesepakatan demi kesepakatan yang diajukan oleh kedua belah pihak yang 
bersifat mengikat satu sama lain. Inti dari kesepakatan tersebut bahwa pihak peladang pendatang harus mengikuti/mentaati ketentuan adat setempat dan juga harus ikut serta membantu kemajuan pembangunan desa setempat. Sedangkan peladang setempat sepakat akan menjaga keamanan dan ketertiban lahan perladangan peladang pendatang. Tercapainya kesepakatan tersebut kedua belah pihak pun sepakat untuk berdamai.

Suksesnya penyelesaian koflik lahan antara peladang pendatang dan peladang setempat di Kecamatan Batang Merangin Kabupaten Kerinci, maka ada perjanjian tidak tertulis Pemerintah Daerah Kabupaten Kerinci kepada kedua belah pihak yaitu akan melakukan kenduri untuk islah. Dengan telah berdamainya pihak peladang pendatang dan peladang setempat maka menurut rencananya akan dilaksanakan pemotongan seekor kerbau yang akan ditanggung oleh Bupati Kerinci H.Adirozal. Akan tetapi, sampai sekarang janji bupati tidak kunjung ditepati. Pihak peladang setempat kembali memberontak akan mengambil lahan perladangan peladang pendatang, sementara pihak peladang pendatang tidak lagi memperdulikannya mereka tetap melakukan aktivitas perladangan seperti biasanya.

\section{Penutup}

Berdasarkan hasil penelitian dan pembahasan yang telah dikemukakan pada bab sebelumnya maka dapat disimpulkan sebagai berikut:

1. Faktor-faktor penyebab terjadinya konflik lahan antara peladang pendatang dan peladang setempat di Kecamatan Batang Merangin Kabupaten Kerinci yaitu perebutan sumber daya, komunikasi yang tidak baik, adanya kecemburuan sosial, dan adanya tindakan pencurian, penjarahan, penyerobotan dan pembakaran rumah ladang milik peladang setempat.

2. Upaya manajemen konflik yang diterapkan dalam penyelesaian konflik lahan antara peladang pendatang dan peladang setempat di Kecamatan Batang Merangin Kabupaten Kerinci adalah menggunakan penyelesaian konflik dengan cara musyawarah (negotiation). Namun tidak tercapai solusi dengan cara musyawarah kemudian mengupayakan penyelesaian masalah dengan cara mediasi (mediation) yang dimediatori oleh Pemerintah Daerah Kabupetan Kerinci, walaupun upaya ini juga belum berhasil menyelesaikan konflik dengan tuntas.

Berdasarkan hasil penelitian maka peneliti mengemukakan saran antara lain bahwa Pemerintah Daerah Kabupaten Kerinci harus membuat kejelasan hukum atas lahan perladangan yang diperebutkan peladang pendatang dan peladang setempat, karena lahan perladangan di daerah Kecamatan Batang Merangin merupakan daerah potensial konflik maka sangat perlunya manajemen konflik untuk jangka panjang mengingat pihak-pihak yang berkonflik belum berdamai secara berkenyataan dan diibaratkan seperti bara (api) dalam sekam. Oleh karena itu, sangat disarankan bapak Bupati yang telah menjanjikan menanggung seekor kerbau untuk kenduri sebagai islah bahwa kedua belah pihak telah kembali rukun/berdamai sebaiknya segera ditunaikan, karena kalau tidak ditunaikan, maka 
dikemudian hari bisa jadi hal itu (janji yang tak terlaksanakan itu) kembali akan menjadi pemicu konflik lagi.

\section{DAFTAR KEPUSTAKAAN}

Lauer, Robert H. (2001). Perspektif Tentang Perubahan Sosial. Jakarta: PT. Rineka Cipta.

Nurman, dkk. (2002). Teori Besar Dalam Sosiologi. Padang: Universitas Negeri Padang.

Rauf, Maswadi. (2001). Konsensus dan Konflik Politik. Jakarta: Departemen Pendidikan Nasional.

Saile, Said. (2008). Pemekaran Wilayah Sebagai Sebuah Demokrasi Di Indonesia. Jakarta: Restu Agung.

Sugiyono. (2014). Metode Penelitian Kuantitatif Kualitatif dan R\&D. Bandung: Alfabeta.

Sukardi. (2016). Penanganan Konflik Sosial Dengan Pendekatan Keadilan Restoratif. Jurnal Hukum dan Pembangunan 46 No.1 (2016): 70-89.

Suryanef dan Syamsir. (2007). "Potensi Konflik Sosial Berbasis Agama di Minangkabau". https://groups.google.com/forum/\#!topic/rantaunet/7gkzZp62VHA

Syamsir. (2002). "Potensi Konflik Sosial Antar Umat Beragama". Jurnal Demokrasi Volume 1 No. 1 tahun 2002.

Wahyu, Acep Supriadi dan Mariatul Kiptiah. (2016). Identifikasi Konflik Perebutan Tanah Adat Di Daerah Lahan Basah Kabupaten Banjar. Jurnal Ilmiah Pendidikan Pancasila dan Kewarganegaraan. Th.1, Nomor 1, Juni 2010. Universitas Lambung Mangkurat.

Walgito, Bimo. (2010). Psikologi Kelompok. Yogyakarta: Penerbit Andi Yogyakarta.

Wirawan. (2010). Konflik dan Manajemen Konflik. Teori, Aplikasi, dan Penelitian. Jakarta: Salemba Humanika. 